\title{
PERAN DUKUNGAN TEMAN SEBAYA DAN REGULASI DIRI BELAJAR TERHADAP PENYESUAIAN AKADEMIS MAHASISWA PERGURUAN TINGGI KEDINASAN BERASRAMA XYZ
}

\author{
Khairun Nisa ${ }^{1}$, Sri Tiatri ${ }^{2}$, Heni Mularsih ${ }^{3}$ \\ ${ }^{1}$ Fakultas Psikologi, Universitas Tarumanagara, Jakarta \\ Email: khairun.nisa@stsn-nci.ac.id \\ ${ }^{2}$ Fakultas Psikologi, Universitas Tarumanagara, Jakarta \\ Email: sri.tiatri@untar.ac.id \\ ${ }^{3}$ Fakultas Psikologi, Universitas Tarumanagara, Jakarta \\ Email: henim@mku.untar.ac.id
}

\begin{abstract}
ABSTRAK
Penyesuaian diri dalam masa transisi dari sekolah menengah ke universitas merupakan hal penting. Salah satu bentuk penyesuaian diri di universitas yaitu penyesuaian akademis. Fenomena yang terjadi pada mahasiswa baru di Sekolah Tinggi XYZ sangat relevan dengan penyesuaian akademis. Berdasarkan hasil penelitian terdahulu oleh Cazan (2012), Kornell \& Metcalfe (2006), Zimmerman \& Schunk (2008), Zakiyah, et.al (2010) serta fenomena yang terjadi di Sekolah Tinggi XYZ, penulis ingin mengetahui bagaimana peran dukungan teman sebaya dan regulasi diri belajar terhadap penyesuaian akademis pada mahasiswa sekolah tinggi XYZ. Mahasiswa merupakan remaja yang sangat memerlukan dukungan teman sebaya. Siswa yang ditolak oleh teman sebaya memiliki masalah penyesuaian yang lebih serius dari pada siswa yang tidak diperdulikan oleh teman sebaya (Santrock, 2011). Selain itu, regulasi diri belajar diketahui sebagai prediktor utama penyesuaian akademis namun belum diteliti apakah dukungan teman sebaya dapat bersama-sama berperan dalam menentukan tingkat penyesuaian akademis mahasiswa. Tujuan penelitian untuk mengetahui peran dukungan teman sebaya dan regulasi diri belajar terhadap penyesuaian akademis mahasiswa. Fenomena terkait penyesuaian akademis di Sekolah Tinggi XYZ menjadi masalah berulang-ulang dan penting untuk diselesaikan, dalam ruang lingkup yang lebih luas, karakteristik partisipan belum banyak diteliti yakni mahasiswa Pendidikan Tinggi Kedinasan. Partisipan 97 mahasiswa tingkat awal. Pengambilan sampel menggunakan teknik non-probability. Teknik analisis data menggunakan uji regresi berganda. Hasil penelitian membuktikan bahwa dukungan teman sebaya dan regulasi diri belajar berperan secara bersama-sama terhadap penyesuaian akademis mahasiswa Sekolah Tinggi Kedinasan Berasrama XYZ, dukungan teman sebaya memiliki peran lebih besar dari pada variabel regulasi diri belajar.
\end{abstract}

Kata Kunci : Penyesuaian akademis, dukungan teman sebaya, regulasi diri belajar, perguruan tinggi kedinasan.

\section{PENDAHULUAN}

Adaptasi sekolah merupakan isu yang sangat luas dipelajari dalam dekade terakhir (Clinciu, 2012). Awal kehidupan universitas diasumsikan membutuhkan penyesuaian terhadap berbagai tuntutan, menjadi proses yang multifaset (Baker \& Siryk, 1999). Transisi ke universitas bisa menjadi pengalaman yang menegangkan bagi banyak mahasiswa baru (Cazan, 2012). Salah satu tantangan penting bagi mahasiswa yaitu kebutuhan untuk mengembangkan kebiasaan belajar dan menyesuaikan strategi pembelajaran untuk lingkungan akademik yang baru. Penyesuaian strategi pembelajaran sebagai salah satu bentuk penyesuaian diri (Bruinsma, 2004; Vermunt, 2005). 
Suatu penelitian pada siswa di pondok pesantren menyatakan bahwa terdapat hubungan yang signifikan antara penyesuaian diri dengan prokrastinasi akademik siswa (Zakiyah, Hidayati, \& Setyawan, 2010). Hubungan yang baik dengan lingkungan, membuat siswa mampu untuk menyesuaikan diri dengan baik di asrama (Zakiyah, Hidayati, \& Setyawan, 2010). Penelitian lain menemukan hubungan negatif yang signifikan antara penyesuaian diri dan dukungan sosial terhadap stres lingkungan pada santri baru (Handono \& Bashori, 2013).

Siswa dengan pendidikan berasrama membutuhkan penyesuaian diri yang baik. Jika penyesuaian diri bermasalah maka akan berdampak buruk. Salah satu bentuk dampak buruk yang muncul yaitu stres lingkungan. Dampak buruk penyesuaian diri juga terjadi di sekolah tinggi kedinasan berasrama XYZ. Mahasiswa tingkat awal harus mampu memenuhi tuntutan lingkungan kampus, antara lain perkuliahan, kegiatan pengasuhan, kegiatan harian mahasiswa, kegiatan senat maupun tata cara sopan santun dalam berinteraksi dengan senior dan orang yang lebih tua di lingkungan kampus.

Salah satu penyesuaian diri yang penting dalam memenuhi tuntutan lingkungan kampus yaitu penyesuaian akademis (Cazan \& Clinciu, 2014). Kesulitan penyesuaian akademis ditemukan pada mahasiswa tingkat awal. Penyesuaian akademis memiliki hubungan yang dekat dengan stres pada mahasiswa tingkat satu (Cazan \& Clinciu, 2013). Beberapa penelitian sebelumnya (Bryant, Schulenberg, Bachman, O'Malley \& Johnston, 2000; Enochs \& Roland, 2006; Martin Jr., Swartz \& Madson, 1999; \& Wintre \& Yaffe, 2000) menunjukkan bahwa kesulitan penyesuaian ditemukan paling umum masalah di kalangan mahasiswa tahun pertama. Mahasiswa akan melalui tahap penyesuaian aktif setelah masuk universitas, dan enam minggu pertama setelah semester pertama dianggap sebagai periode krusial dalam menentukan retensi (Molnar, 1993). Penyesuaian yang berhasil, tercermin dalam perilaku belajar siswa dan prestasi akademis (Cazan, 2012).

Penyesuaian akademis yang berhasil dipengaruhi beberapa faktor antara lain regulasi diri. Regulasi diri berkaitan dengan prestasi akademik dan penyesuaian akademis (Kornell \& Metcalfe, 2006; Zimmerman \& Schunk, 2008). Pengaturan diri secara keseluruhan sangat terkait dengan penyesuaian akademis (Cazan, 2012). Salah satu regulasi diri yang merupakan prediktor penyesuaian akademis yaitu regulasi diri belajar (self-regulated learning). Strategi regulasi diri belajar, efikasi diri akademik, dan kecemasan sebagai prediktor penyesuaian akademis, dimana prediktor terkuat yaitu strategi pengaturan diri belajar metakognitif (Cazan, 2012).

Salah satu faktor yang dimungkinkan berperan dalam penyesuaian akademis mahasiswa yaitu dukungan sosial, sebagaimana penelitian terdahulu yang relevan menyatakan bahwa dukungan sosial dan penyesuaian diri berhubungan signifikan dengan stres lingkungan pada santri (Handono \& Bashori, 2013). Dukungan sosial dalam penelitian sebelumnya tidak terlalu spesifik menjelaskan tentang dukungan teman sebaya. Penempatan dukungan teman sebaya dan penyesuaian diri pun sebagai variabel independen. Teman sebaya merupakan lingkungan sosial yang sangat penting bagi remaja. Oleh karena itu, penulis menilai faktor dukungan teman sebaya pada penelitian ini menjadi faktor yang berbeda dengan faktor dukungan sosial seperti dalam penelitian sebelumnya.

Siswa yang memiliki teman dan terlibat dalam perilaku prososial lebih memiliki nilai akademik lebih tinggi, dan kurang tertekan secara emosional (Santrock, 2011). Siswa yang ditolak oleh teman sebaya memiliki masalah penyesuaian yang lebih serius dari pada siswa yang tidak 
diperdulikan oleh teman sebaya (Santrock, 2011). Teman sebaya merupakan anak-anak dengan usia atau tingkat kematangan yang sama (Santrock, 2011).

Afiliasi teman berhubungan dengan penyesuaian sekolah, sedangkan dukungan teman atau dukungan orang tua sebagai variabel moderasi dalam hubungan ini (Espinoza, O'neel, Gonzales, \& Fuligni, 2014). Penelitian Espinoza, et.al (2014) ini memiliki variabel yang berbeda. Variabel dependen dalam penelitian tersebut merupakan penyesuaian sekolah secara umum. Afiliasi teman dalam penelitian ini sebagai variabel independen. Afiliasi teman merupakan faktor eksternal bagi siswa, demikian juga dukungan teman dan dukungan orang tua. Maka, penulis menegaskan bahwa penelitan ini berbeda dengan penelitian Espinoza, et.al (2014) ini. Pada penelitian ini, penulis menempatkan dukungan teman sebaya sebagai variabel independen bukan sebagai variabel moderasi. Dukungan teman sebaya merupakan faktor eksternal mahasiswa, sedangkan regulasi diri belajar merupakan faktor internal mahasiswa.

Sekolah Tinggi XYZ adalah salah satu perguruan tinggi kedinasan yang didirikan berdasarkan Keputusan Presiden RI No. 22 tahun 2003 tanggal 17 April 2003. Sekolah ini menganut sistem pendidikan semi militer berasrama. Jumlah mahasiswa tingkat I sampai dengan tingkat IV tahun akademik 2017/2018 yaitu 327 orang, yang terdiri dari 206 mahasiswa dan 121 mahasiswi. Fenomena yang terjadi pada mahasiswa baru di Sekolah Tinggi XYZ sangat relevan dengan penyesuaian akademis. Beban materi perkuliahan yang relatif berat dengan sistem putus kuliah (drop out) per semester serta kehidupan berasrama dengan segala dinamikanya, bukan hal yang mudah untuk dilalui.

Data akademik mahasiswa dalam kurun waktu 2013-2016 menunjukkan bahwa setiap tahun sejumlah 2-3 mahasiswa dari sekitar 80 mahasiswa tingkat I harus putus kuliah yang disebabkan nilai akademik yang tidak mencapai target minimal kelulusan maupun terlibat kasus perilaku yang melanggar aturan. Namun, sebagian mahasiswa lain mampu bertahan dan memiliki prestasi akademik yang optimal. Prestasi akademik dipengaruhi oleh penyesuaian yang dimiliki oleh peserta didik. Sebagaimana dikemukakan oleh Cazan (2012) bahwa penyesuaian yang berhasil tercermin dalam perilaku belajar siswa dan dalam prestasi akademik. Penanganan atas permasalahan penyesuaian akademis ini belum mendapatkan hasil yang diinginkan oleh penyelenggara. Penanganan yang telah dilakukan yaitu seperti memberi konseling kepada mahasiswa yang bermasalah secara akademik oleh pembimbing psikologis, dan pemberian mentoring dari dosen di luar jam perkuliahan kepada mahasiswa yang memiliki masalah akademik. Prestasi akademik mahasiswa tingkat awal masih jauh dari yang diharapkan penyelenggara.

Prestasi akademik yang relatif rendah tergambar dalam jumlah peserta ujian remedial yang tinggi pada mahasiswa tingkat I. Data Sub Bagian Administrasi Akademik dan Kerjasama Sekolah Tinggi XYZ menyebutkan jumlah mahasiswa yang harus mengikuti remedial tiap semester dalam kurun waktu 5 tahun terlihat dalam tabel 1 berikut.

Tabel 1

Jumlah mahasiswa tingkat I remedial per semester selama 5 tahun akademik

\begin{tabular}{cccc}
\hline Tahun Akademik & Semester & $\begin{array}{c}\text { Jumlah Mahasiswa } \\
\text { Remedial (\%) }\end{array}$ & $\begin{array}{c}\text { Total } \\
\text { Mahasiswa }\end{array}$ \\
\hline $2016 / 2017$ & Gasal & $19(23,8 \%)$ & 80 \\
\hline
\end{tabular}




\begin{tabular}{cccc}
\hline & Genap & $31(38,8 \%)$ & 80 \\
\hline $205 / 2016$ & Gasal & $44(55 \%)$ & 80 \\
\hline & Genap & $48(60 \%)$ & 80 \\
\hline $2014 / 2015$ & Gasal & $36(45 \%)$ & 80 \\
\hline & Genap & $40(50 \%)$ & 80 \\
\hline $2013 / 2014$ & Gasal & $55(68,75 \%)$ & 80 \\
\hline & Genap & $40(50 \%)$ & 80 \\
\hline $2012 / 2013$ & Gasal & $20(50 \%)$ & 40 \\
\hline & Genap & $15(37,5 \%)$ & 40 \\
\hline
\end{tabular}

Penelitian terdahulu yang menjadi acuan dalam penelitian ini yaitu penelitian yang menjelaskan bahwa regulasi diri belajar metakognitif sebagai prediktor dalam penyesuaian akademis (Cazan, 2012). Penelitian ini tidak mengkhususkan hanya pada dimensi metakognitif dalam regulasi diri belajar, namun memperhatikan peran regulasi diri belajar pada lingkup strategi pembelajaran, dimana metakognitif sebagai salah satu dimensi didalamnya.

Berdasarkan uraian hasil penelitian-penelitian sebelumnya tentang variabel penyesuaian akademis, serta fenomena yang terjadi di Sekolah Tinggi XYZ, maka penulis ingin mengetahui bagaimana peran dukungan teman sebaya dan regulasi diri belajar terhadap penyesuaian akademis pada mahasiswa sekolah tinggi XYZ. Regulasi diri belajar metakognitif telah diketahui sebagai prediktor utama penyesuaian akademis, namun belum diteliti apakah dukungan teman sebaya juga dapat berperan dalam penyesuaian akademis mahasiswa. Hal ini karena mempertimbangkan pentingnya peran teman sebaya pada tahap perkembangan remaja yang merupakan partisipan dalam penelitian ini.

Ketertarikan penulis akan penelitian ini karena penulis belum menemukan penelitian yang mengupas secara eksplisit tentang peran dukungan teman sebaya dan regulasi diri belajar secara bersama-sama terhadap penyesuaian akademis. Selain itu, fenomena terkait penyesuaian akademis di Sekolah Tinggi XYZ menjadi masalah berulang-ulang dan mendesak untuk segera diselesaikan. Karakteristik partisipan dalam penelitian ini pun belum banyak diteliti yaitu mahasiswa pada Perguruan Tinggi Kedinasan yang berbeda dengan mahasiswa perguruan tinggi lainnya di Indonesia.

\section{Rumusan Masalah}

Rumusan masalah penelitian ini yaitu: (1) apakah dukungan teman sebaya memiliki peran dalam penyesuaian akademis mahasiswa sekolah tinggi kedinasan berasrama XYZ?, (2) apakah regulasi diri belajar memiliki peran terhadap penyesuaian akademis mahasiswa sekolah tinggi kedinasan berasrama XYZ?, dan (3) apakah dukungan teman sebaya dan regulasi diri belajar secara bersamasama memiliki peran terhadap penyesuaian akademis mahasiswa sekolah tinggi kedinasan berasrama XYZ?. Adapun tujuan penelitian ini yaitu untuk mengetahui peran dukungan teman sebaya dan regulasi diri belajar terhadap penyesuaian akademis mahasiswa sekolah tinggi kedinasan berasrama XYZ.

\section{METODE PENELITIAN}

Jumlah partisipan yaitu 97 mahasiswa Sekolah Tinggi XYZ dengan batasan karakteristik: (1) Rentang usia 17 tahun sampai dengan 19 tahun; dan (2) mahasiswa Sekolah Tinggi XYZ status aktif yang sedang menjalani masa pendidikan di tahun pertama. Mahasiswa merupakan lulusan 
SMU jurusan IPA tahun 2016 dan 2017. Mahasiswa baru memiliki potensi intelektual dengan range IQ skala IST 110-130 (data Bagian Administrasi Akademik dan Kemahasiswaan, Sekolah Tinggi XYZ).

Teknik pengambilan sampel yaitu teknik non-probability sampling. Pengambilan sampel ini dapat menggunakan metode purposive sampling. Teknik penarikan sampel yang digunakan karena peneliti memiliki pengetahuan yang memadai tentang karakteristik populasi.

Desain penelitian merupakan penelitian non-eksperimental dengan pendekatan kuantitatif. Pengambilan data menggunakan alat ukur tiga variabel penelitian yang diadaptasi dari alat ukur yang sudah pernah digunakan dalam penelitian-penelitian sebelumnya. Adapun teknik pengolahan data dengan metode statistika regresi linier berganda di mana terdapat satu variabel dependen dan dua variabel independen. Teknik penghitungan regresi berganda ini dilakukan dengan bantuan aplikasi SPSS versi 21.

Pengukuran variabel penyesuaian akademis menggunakan adaptasi alat ukur Academic Adjustment Questionnaire (AAQ) yang dikembangkan pertama kali oleh Cazan dan Clinciu (2013). Alat ukur memiliki 24 butir pernyataan yang tercakup dalam 2 dimensi. Setelah dilakukan uji validitas isi, face validity, dan uji realibilitas, maka ditentukan 17 butir dipertahankan dan 7 butir dihilangkan. Setelah penulis menghilangkan 7 butir dan melakukan uji realibilitas butir alat ukur maka skor Cronbach's Alpha sebesar 0,710. Alat ukur variabel penyesuaian akademis dapat dikatakan reliabel karena skor Cronbach's Alpha di atas angka 0,700.

Pengukuran variabel dukungan teman sebaya menggunakan adaptasi alat ukur Interpersonal Support Evaluation List (ISEL) College Version yang dikembangkan pertama kali oleh Cohen dan Hoberman (1983). Alat ukur memiliki 46 butir pernyataan yang tercakup dalam 4 dimensi. Setelah dilakukan uji validitas isi, face validity, dan uji realibilitas, maka ditentukan 29 butir dipertahankan dan 17 butir dihilangkan. Setelah penulis menghilangkan 17 butir dan melakukan uji realibilitas butir alat ukur maka skor Cronbach's Alpha sebesar 0,823. Alat ukur variabel dukungan teman sebaya dapat dikatakan reliabel karena skor Cronbach's Alpha di atas angka 0,700.

Pengukuran variabel regulasi diri belajar menggunakan adaptasi alat ukur Motivated Strategies For Learning Questionnaire (MSLQ) yang dikembangkan pertama kali oleh Pintrich, et.al. (1983). Alat ukur memiliki 50 butir pernyataan yang tercakup dalam 9 dimensi. Setelah dilakukan uji validitas isi, face validity, dan uji realibilitas, maka ditentukan 43 butir dipertahankan dan 7 butir dihilangkan. Setelah penulis menghilangkan 7 butir dan melakukan uji realibilitas butir alat ukur dan maka skor Cronbach's Alpha sebesar 0,934. Alat ukur variabel regulasi diri belajar dapat dikatakan reliabel karena skor Cronbach's Alpha di atas angka 0,700.

\section{HASIL DAN PEMBAHASAN}

Berdasarkan jenis kelamin dari 97 partisipan terdiri dari 66 laki-laki $(68,1 \%)$ dan 31 perempuan (31,9\%). Sedangkan berdasarkan tahun lulus, sejumlah 16 mahasiswa (16,5\%) lulus tahun 2016 sedangkan 83 mahasiswa $(83,5 \%)$ lulus pada tahun 2017.

Berdasarkan data pengukuran variabel penyesuaian akademis, skor minimum 23 dan skor maksimum 34, maka nilai rata-rata empirik variabel penyesuaian akademis sebesar 30,68. 
Sedangkan nilai rata-rata hipotetik sebesar 25,5. Maka dapat dikatakan tingkat penyesuaian akademis partisipan tergolong tinggi. Sedangkan simpangan baku sebesar 2,68, maka wilayah data penyesuaian akademis berada pada kisaran $95,4 \%$ atau rata-rata jarak penyimpangan titik-titik data diukur dari nilai rata-rata data tersebut sebesar $95,4 \%$.

Berdasarkan data pengukuran variabel dukungan teman sebaya, skor minimum 42 dan skor maksimum 58, maka nilai rata-rata empirik variabel dukungan teman sebaya sebesar 51,63. Sedangkan nilai rata-rata hipotetik sebesar 43,5. Maka dapat dikatakan tingkat persepsi dukungan teman sebaya dari partisipan jauh di atas nilai rata-rata hipotetik atau tergolong tinggi. Sedangkan simpangan baku dukungan teman sebaya sebesar 4,48; maka wilayah data dukungan teman sebaya berada pada kisaran $99,7 \%$ atau rata-rata jarak penyimpangan titik-titik data diukur dari nilai ratarata data tersebut sebesar $99,7 \%$.

Berdasarkan data pengukuran variabel regulasi diri belajar, skor minimum 132 dan skor maksimum 292, maka nilai rata-rata empirik variabel regulasi diri belajar sebesar 218,16. Sedangkan nilai rata-rata hipotetik sebesar 177. Maka dapat dikatakan tingkat regulasi diri belajar partisipan jauh di atas nilai rata-rata atau tergolong tinggi. Sedangkan simpangan baku regulasi diri belajar sebesar 31,67; maka wilayah data regulasi diri belajar berada pada kisaran 99,7\% atau rata-rata jarak penyimpangan titik-titik data diukur dari nilai rata-rata data tersebut sebesar $99,7 \%$.

Uji hipotesis 1 menyatakan bahwa dukungan teman sebaya berpengaruh positif dan signifikan terhadap penyesuaian akademis mahasiswa sekolah tinggi kedinasan berasrama XYZ. Hipotesis 1 dapat dibuktikan melalui uji korelasi antara variabel, seperti terlihat dalam tabel 2 berikut ini.

Tabel 2

Korelasi Antar Variabel Penelitian

\begin{tabular}{|c|c|c|c|c|}
\hline & & $\begin{array}{l}\text { Penyesuaia } \\
\text { n Akademis }\end{array}$ & $\begin{array}{c}\text { Dukungan } \\
\text { Teman Sebaya }\end{array}$ & Regulasi Diri Belajar \\
\hline \multirow{3}{*}{$\begin{array}{l}\text { Penyesuaia } \\
\text { n Akademis }\end{array}$} & $\begin{array}{l}\text { Pearson } \\
\text { Correlation }\end{array}$ & 1 & $0,573^{* *}$ & $0,306 * *$ \\
\hline & Sig. (2-tailed) & & 0,000 & 0,002 \\
\hline & $\mathrm{N}$ & 97 & 97 & 97 \\
\hline
\end{tabular}

Skor korelasi Pearson pada korelasi variabel dukungan teman sebaya dan penyesuaian akademis sebesar 0,573 atau sebesar $57,3 \%$. Hal ini berarti variabel dukungan teman sebaya memiliki pengaruh yang kuat terhadap variabel penyesuaian akademis. Korelasi positif menunjukkan bahwa semakin tinggi persepsi mahasiswa terhadap dukungan teman sebaya maka semakin tinggi tingkat penyesuaian akademis mahasiswa.

Uji hipotesis 2 menyatakan bahwa regulasi diri belajar berpengaruh positif dan signifikan terhadap penyesuaian akademis mahasiswa sekolah tinggi kedinasan berasrama XYZ. Hipotesis 2 dibuktikan melalui uji korelasi antara variabel, seperti terlihat dalam tabel 7 berikut ini.

Skor korelasi Pearson pada korelasi variabel regulasi diri belajar dan penyesuaian akademis sebesar 0,306 atau sebesar 30,6\%. Hal ini berarti variabel regulasi diri belajar memiliki pengaruh yang lemah (skor<0,5) terhadap variabel penyesuaian akademis. Skor positif menunjukkan korelasi positif, bahwa semakin tinggi regulasi diri belajar maka semakin tinggi tingkat penyesuaian akademis mahasiswa. 
Uji hipotesis 3 sebagaimana diperlihatkan tabel 8 hasil uji F. F hitung sebesar 25,606 dengan tingkat signifikansi 0,000. Probabilitas menunjukkan 0,000 jauh lebih kecil dari 0,05 , maka model regresi dapat dipakai untuk memprediksi variabel penyesuaian akademis atau dengan kata lain variabel dukungan teman sebaya dan regulasi diri belajar secara bersama-sama berpengaruh (korelasi) terhadap penyesuaian akademis.

Tabel 3

Uji F

\begin{tabular}{llccccc}
\hline \multirow{2}{*}{ Model } & $\begin{array}{c}\text { Sum of } \\
\text { Squares }\end{array}$ & df & $\begin{array}{c}\text { Mean } \\
\text { Square }\end{array}$ & F & Sig. \\
\hline \multirow{3}{*}{1} & Regression & 243,022 & 2 & 121,511 & 25,606 & $0,000^{\mathrm{b}}$ \\
\cline { 2 - 7 } & Residual & 446,071 & 94 & 4,745 & & \\
\cline { 2 - 7 } & Total & 689,093 & 96 & & & \\
\hline
\end{tabular}

a. Dependent Variable: Penyesuaian Akademis

b. Predictors: (Constant), Dukungan Teman Sebaya, Regulasi Diri Belajar.

Berdasarkan tabel 9 di bawah ini diketahui bahwa angka $R$ square adalah 0,353. Hal ini berarti $35,3 \%$ dari variasi penyesuaian akademis mahasiswa bisa dijelaskan oleh faktor dukungan teman sebaya dan regulasi diri belajar. Sedangkan sisanya sebesar $64,7 \%$ dijelaskan oleh sebab-sebab yang lain.

Tabel 4

Tabel koefisien determinasi

\begin{tabular}{ccccc}
\hline Model & $\mathrm{R}$ & $\mathrm{R}$ Square & Adjusted R Square & Std. Error of the Estimate \\
\hline 1 & $0,594^{\mathrm{a}}$ & 0,353 & 0,339 & 2,178 \\
\hline
\end{tabular}

a. Predictors: (Constant), Dukungan Teman Sebaya, Regulasi Diri Belajar

b. Dependent Variable: Penyesuaian Akademis

Tabel 5 menjelaskan koefisien masing-masing variabel pada persamaan regresi linier. Berdasarkan tabel 16, maka persamaan regresi penelitian ini dirumuskan sebagai: $\mathrm{Y}=11,365+0,316 \mathrm{X} 1+$ $0,014 \mathrm{X} 2$, di mana $\mathrm{Y}=$ penyesuaian akademis, $\mathrm{X} 1=$ dukungan teman sebaya, dan $\mathrm{X} 2=$ regulasi diri belajar. Hal ini menunjukkan bahwa konstanta sebesar 11,365, sehingga dinyatakan bahwa jika mahasiswa tidak memiliki persepsi dukungan teman sebaya dan regulasi diri belajar maka tingkat penyesuaian akademis hanya sebesar 11,365.

Koefisien regresi X1 sebesar 0,316 menyatakan bahwa setiap penambahan 31,6\% persepsi dukungan teman sebaya akan meningkatkan penyesuaian akademis sebesar $31,6 \%$. Sedangkan koefisien regresi X2 sebesar 0,014 menyatakan bahwa setiap penambahan 1,4\% regulasi diri belajar akan meningkatkan penyesuaian akademis sebesar 1,4\%. Penjelasan ini menunjukkan bahwa peran dukungan teman sebaya jauh lebih besar dibandingkan peran regulasi diri belajar terhadap penyesuaian akademis mahasiswa, dengan selisih sebesar 30,2\%. 


\begin{tabular}{|c|c|c|c|c|c|c|}
\hline & \multirow[t]{2}{*}{ Model } & \multicolumn{2}{|c|}{$\begin{array}{c}\text { Unstandardized } \\
\text { Coefficients }\end{array}$} & \multirow{2}{*}{$\begin{array}{c}\begin{array}{c}\text { Standardize } \\
\text { d }\end{array} \\
\text { Coefficients }\end{array}$} & \multirow[t]{2}{*}{$\mathbf{t}$} & \multirow[t]{2}{*}{ Sig. } \\
\hline & & B & $\begin{array}{l}\text { Std. } \\
\text { Error }\end{array}$ & & & \\
\hline \multirow{3}{*}{1} & (Constant) & 11,365 & 2,713 & & 4,189 & 0,000 \\
\hline & $\begin{array}{l}\text { Dukungan Teman } \\
\text { Sebaya }\end{array}$ & 0,316 & 0,051 & 0,528 & 6,130 & 0,000 \\
\hline & Regulasi Diri Belajar & 0,014 & 0,007 & 0,163 & 1,896 & 0,061 \\
\hline
\end{tabular}

a. Dependent Variable: Penyesuaian Akademis

Ketiga hipotesis dinyatakan diterima. Adapun jawaban pembuktian hipotesis penelitian ini, yaitu: (a) dukungan teman sebaya berpengaruh positif dan signifikan terhadap penyesuaian akademis mahasiswa sekolah tinggi kedinasan berasrama XYZ; (b) regulasi diri belajar berpengaruh positif dan signifikan terhadap penyesuaian akademis mahasiswa sekolah tinggi kedinasan berasrama XYZ; (c) dukungan teman sebaya dan regulasi diri belajar secara bersama-sama berpengaruh positif dan signifikan terhadap penyesuaian akademis mahasiswa sekolah tinggi kedinasan berasrama XYZ.

Hasil pengujian hipotesis membuktikan ke tiga hipotesis tersebut, maka hasil penelitian sebagai berikut: (a) dukungan teman sebaya memiliki peran dalam penyesuaian akademis mahasiswa sekolah tinggi kedinasan berasrama XYZ, (b) regulasi diri belajar memiliki peran terhadap penyesuaian akademis mahasiswa sekolah tinggi kedinasan berasrama XYZ, dan (c) dukungan teman sebaya dan regulasi diri belajar secara bersama-sama memiliki peran terhadap penyesuaian akademis mahasiswa sekolah tinggi kedinasan berasrama XYZ.

Penjelasan tentang korelasi antar variabel menunjukkan bahwa korelasi antara variabel dukungan teman sebaya dan variabel penyesuaian akademis memiliki tingkat korelasi yang cukup kuat dengan arah hubungan yang sama. Sedangkan korelasi antara variabel regulasi diri belajar dan variabel penyesuaian akademis menunjukkan tingkat korelasi yang cenderung lebih lemah bila dibandingkan dengan korelasi antara variabel dukungan teman sebaya dan penyesuaian akademis, dengan arah hubungan yang sama. Hasil penelitian ini masih relevan dengan penelitian sebelumnya oleh Cazan (2012), yang menyatakan bahwa regulasi diri belajar merupakan prediktor kuat dalam penyesuaian akademis. Meskipun, hasil analisis data menunjukkan peran yang cenderung lebih lemah pada variabel regulasi diri belajar dibandingkan variabel dukungan teman sebaya. Hal ini dimungkinkan dapat terjadi karena mahasiswa merupakan remaja yang sangat mementingkankan dukungan sosial teman sebaya dalam menghadapi tuntutan-tuntutan akademis di universitas. Selain itu mahasiswa mengikuti pendidikan berasrama yang juga menuntut mahasiswa mandiri karena jauh dari orang tua. Sehingga dimungkinkan dukungan teman sebaya lebih berperan dibandingkan regulasi diri belajar terhadap penyesuaian akademis dibandingkan dukungan orang tua yang juga jauh keberadaannya.

Pembuktian bahwa dukungan teman sebaya lebih memiliki peran dibandingkan regulasi diri belajar, menurut penulis juga lebih sebagai konteks lingkungan pembelajaran maupun usia perkembangan peserta didik sebagai karakteristik kuat subyek penelitian. Tuntutan untuk menjadi lebih mandiri dalam segala aspek selama mengikuti pendidikan sebenarnya juga menuntut regulasi diri yang matang, karena kehidupan asrama dengan sistem semi militer 
sarat dengan pengaturan dalam bersikap dan berperilaku bagi mahasiswa. Selain itu, dependensi mahasiswa dengan orang tua dan perasaan homesick, mungkin saja mempengaruhi penyesuaian akademisnya pada saat mengikuti pendidikan berasrama.

\section{KESIMPULAN DAN SARAN}

Kesimpulan penelitian ini yaitu dukungan teman sebaya berperan terhadap penyesuaian akademis mahasiswa, demikian juga variabel regulasi diri belajar berperan terhadap variabel penyesuaian akademis. Kedua variabel independen secara bersamaan berperan pada penyesuaian akademis mahasiswa Sekolah Tinggi XYZ. Dukungan teman sebaya memiliki peran yang lebih kuat dibandingkan regulasi diri belajar terhadap penyesuaian akademis. Namun demikian, kedua variabel independen memiliki peran positif terhadap penyesuaian akademis, hal ini berarti bahwa peningkatan dukungan teman sebaya berperan dalam meningkatkan penyesuaian akademis mahasiswa, demikian pula halnya peningkatan regulasi diri belajar berperan dalam meningkatkan penyesuaian akademis mahasiswa.

Saran bagi penyelenggara pendidikan agar lebih memberikan perhatian pada penyesuaian akademis mahasiswa, khususnya pada penyesuaian akademis mahasiswa tingkat awal. Kehidupan berasrama dengan dinamika sosial di dalamnya, seperti bagaimana mahasiswa berinteraksi dengan teman se-angkatan maupun interaksi dengan kakak angkatan perlu diperhatikan, agar konflik sosial antar angkatan dapat diminimalisir atau dieliminasi. Selain itu, perlu diperhatikan bagaimana mahasiswa mengatur diri mereka sendiri dalam menjalani proses pembelajaran. Perlu diberikan materi tambahan di luar materi kuliah dalam bentuk pelatihan menyusun rencana dan tujuan pembelajaran individu. Tujuan pelatihan agar mahasiswa mampu merealisasikan regulasi diri belajar yang tepat dan konkret agar pencapaian penyesuaian akademis dapat lebih pasti. Selain itu, perlu diberikan konseling kepada mahasiswa mengenai bagaimana mengembangkan persepsi positif terhadap dukungan teman sebaya. Pelatihan dan konseling akan diberikan oleh praktisi atau narasumber di bidang Psikologi Pendidikan.

Saran bagi mahasiswa yaitu bagaimana mahasiswa mampu membangun persepsi yang lebih positif tentang dukungan teman sebaya seperti meyakini bahwa teman sebaya akan memberikan dukungan yang dibutuhkan oleh mahasiswa dalam menghadapi tuntutan akademik. Langkahlangkah konkret yang mungkin dapat dilakukan dalam membangun persepsi positif tentang dukungan teman sebaya seperti: lebih terbuka dan mau bercerita permasalahan atau kesulitan yang dihadapi kepada teman seangkatan, tidak merasa malu atau sungkan meminta bantuan baik yang bersifat materil maupun moril kepada teman seangkatan, serta menjalin hubungan dan interaksi sosial yang lebih hangat dan akrab dengan teman seangkatan. Persepsi yang positif ini kemudian dikembangkan kepada pengaturan diri belajar yang lebih realistis dan tepat dalam proses pembelajaran. Dengan demikian, secara bertahap penyesuaian akademis akan tercapai.

\section{Ucapan Terima Kasih}

Ucapan terima kasih penulis sampaikan kepada pihak-pihak yang mendukung penelitian ini diantaranya kepada Ibu Dr. Riana Sahrani, M.Si., Psikolog, atas masukannya dalam proses pengujian adaptasi alat ukur penelitian, Bapak Tundung Himawan, S.S., M.Si., dan Ibu Nurasa, S.Pd selaku narasumber translasi dalam proses adaptasi alat ukur. Akhirnya tak lupa juga penulis sampaikan terima kasih kepada Ketua Sekolah Tinggi XYZ beserta sivitas akademik atas izin melakukan penelitian di institusinya, serta mahasiswa-mahasiswi tingkat I Sekolah Tinggi Kedinasan XYZ atas kesediaannya menjadi partisipan penelitian ini. 


\section{REFERENSI}

Baker, R. E., \& Siryk, B. (1999). Student adaptation to college questionnaire manual . Los Angeles, CA: Western Psychological Services.

Boekaerts, M., Pintrich, P. R., \& Zeidner, M. (Eds.). (2000). Handbook of Self-Regulation. San Diego, CA: Academic Press.

Bruinsma, M. (2004). Motivation, cognitive processing and achievement in higher education. Learning and Instruction, 14, 549-568.

Cazan, A. M. (2012). Self regulated learning strategies-predictors of academic adjustment. Procedia-Social and Behavioral Sciences, 33, 104-108.

Clinciu, A. I., \& Cazan, A. M. (2014). Academic Adjustment Questionnaire for the university students. Procedia-Social and Behavioral Sciences, 127, 655-660.

Clinciu, A. I. (2012). Adaptation and stress for the first year university students. Procedia-Social and Behavioral Sciences, $78,718-722$.

Enochs, W. K., \& Roland, C. B. (2006). Social adjustment to college freshmen: the importance of gender and living environment. College Student Journal, 40 (1), 63-72.

Espinoza, G., O’Neel, C.G., Gonzales, N.A., Fuligni, A. J. (2014). Friend affiliations and school adjustment among mexican-american adolescents: the moderating role of peer and parent support. J Youth Adolescence 43:1969-1981. DOI 10.1007/s10964-013-0023-5.

Handono, O. T., \& Bashori, K. (2013). Hubungan antara penyesuaian diri dan dukungan sosial terhadap stres lingkungan pada santri baru. Empathy Jurnal Fakultas Psikologi Fakultas Psikologi Universitas Ahmad Dahlan Yogyakarta, Vol. 1, No 2, Desember 2013.

Kornell, N., \& Metcalfe, J. (2006). Study efficacy and the region of proximal learning framework. Journal of Experimental Psychology: Learning, Memory, and Cognition, 32, 609-622.

Molnar, D. (1993). The impact of mission effectiveness on student retention. Annual Forum of the Association for Institutional Research, Chicago, Il. (ERIC Document Reproduction Service No. ED360940).

Pintrich, P. R., Smith, D. A. F., Garcia, T., \& McKeachie, W. J. (1991). A manual for the use of the Motivated Strategies for Learning Questionnaire (MSLQ). Michigan: The University of Michigan.

Santrock, J.W. (2004). Life-Span Development ( $9^{\text {th }}$ Ed.). New York: McGraw-Hill.

Santrock, J.W. (2007). Adolescence (1 $1^{\text {th }}$ Ed.). New York: McGraw-Hill.

Santrock, J.W. (2011). Educational Psychology (5 $5^{\text {th }}$ Ed.). New York: McGraw-Hill.

Schunk, D. H., \& Zimmerman, B. J. (Eds.). (1994). Self-Regulation OfLearning and Performance: Issues and Educational Applications. NJ: Erlbaum.

Schunk, D. H., \& Zimmerman, B. J. (Eds.). (1998). Self-Regulated Learning: from Teaching to Self-Reflective Practice. New York: Guilford Press.

Schunk, D.H. (2005). Self-regulated learning: The educational legacy of Paul R. Pintrich. Educational Psychologist, 40, 85-94.

Zakiyah, N., Hidayati, F. N. R., \& Setyawan, I. (2010). Hubungan antara penyesuaian diri dengan prokrastinasi akademik siswa sekolah berasrama SMP N 3 Peterongan Jombang. Jurnal Psikologi Undip, Vol. 8, No.2, Oktober 2010.

Zimmerman, B. J. (1989). A social cognitive view of self-regulated academic. learning. Journal of Educational Psychology, 81, 329-339.

Zimmerman, B. J. (1990). Self-regulated learning and academic achievement: an overview. Educational Psychologist, 25(1), 3-17. 
Zimmerman, B. J. (1998). Academic studying and the development of personal skill: a selfregulatory perspective. Educational Psychologist, 33,73-86.

Zimmerman, B. J. (2000). Attaining self-regulation: a social cognitive perspective. In: Boekaerts M, Pintrich P. R, Zeidner M, eds. Handbook of Self-Regulation. Mahwah, NY: Academic Press. 